\title{
Main infections in the children under 5 years old in developing countries: reports and perspectives Christian Courpotin
}

\author{
Address: SOLTHIS, Paris, France \\ from Fourth Dominique Dormont International Conference. Host-Pathogen Interactions in Chronic Infections \\ Paris, France. 13-15 December 2007 \\ Published: 9 April 2008 \\ Retrovirology 2008, 5(Suppl I):L8 doi:I0.II86/I742-4690-5-SI-L8
}

This abstract is available from: http://www.retrovirology.com/content/5/SI/L8

(C) 2008 Courpotin; licensee BioMed Central Ltd.

Spectacular progress in reducing under 5 mortality achieved in the last few decades is projected to continue. There were about 11 million such deaths in 1997 compared to 21 million in 1955.

The under-5 mortality rates per 1000 live births was 210 in 1955 and is projected to be 37 in 2025 . Today about 29,000 children under the age of five - 21 each minute die every day of the 10.5 million deaths in children under five a year. Two-thirds of deaths occur in just 10 countries and almost half of them occur in sub-Saharan Africa, where progress has slowed due to lack of preventive care and treatment, fragile health systems, and socio-economic stagnation due to conflicts, instability and AIDS. According to the 2005 World Health's report near by $90 \%$ of the less than 5 years old children's deaths are related to six major diseases: acute newborn's problem (mainly prematurity, apparent neonatal death, infections (37\%)), lower respiratory tract infections mainly pneumonia (19\%), diarrhoea $(18 \%)$, paludism $(8 \%)$, measles $(4 \%)$ and HIV/AIDS (3\%). About 50\% of deaths among children under 5 are associated with malnutrition. But disease isn't inevitable, nor do children with these diseases need to die. Research and experience show that six million of the almost 10.5 million children who die each year could be saved by low-tech, evidence-based, cost-effective measures such as vaccines, antibiotics, micronutrient supplementation, insecticide-treated bed nets and improved family care and breastfeeding practices. In 2000, the millennium goals where defined by WHO. The goal number 4 is to reduce child mortality by two-thirds, from 93 children of every 1,000 dying before age five in 1990 to 31 of every 1,000 in 2015 . Are we on the way to succeed? 